\title{
DNA polymorphism and molecular pathology of the human globin gene clusters
}

Stylianos E. Antonarakis, Haig H. Kazazian, Jr., and Stuart H. Orkin

Hum Genet (1985) 69:1-14

Although the reference list of the above paper was alphabetized and renumbered accordingly during the editorial process, the numbers in the text were not changed to agree. Therefore, pp.3 and 12-14 are being reprinted to agree with the text. Please substitute these pages for those originally published. 

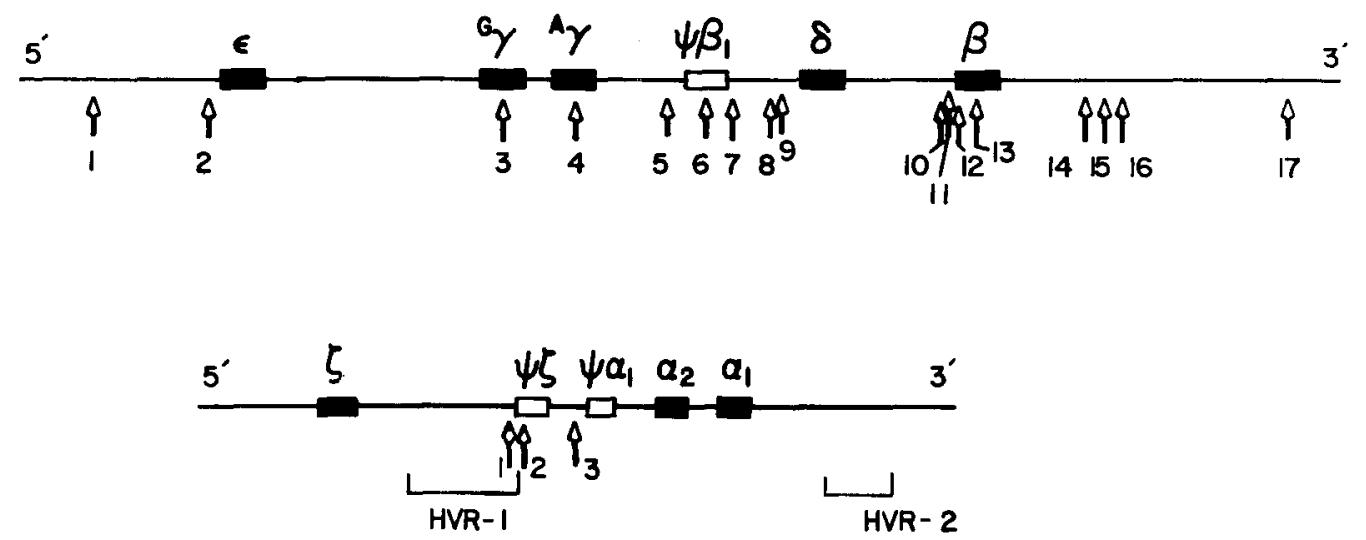

Fig. 2. A Location of the useful polymorphic restriction sites in the $\beta$-globin gene cluster. Each polymorphic site is shown by an open arrow. The sites are: 1. Taq I (16), 2. Hinc II (1), 3. Hind III (38), 4. Hind III (38), 5. Pvu II (65), 6. Hinc II (1), 7. Hinc II (1), 8. Rsa I (58), 9. Taq I (58), 10. Hinf I (62), 11. Rsa I (97), 12. HgiA I (72), 13. Ava II (1), 14. Hpa I (41), 15. Hind III (108), 16. Bam HI (45), 17. Rsa (16). B Location of the DNA polymorphisms in the globin gene cluster. HVR: Highly variable region. The sites are: 1. EcoRI (10), 2. Sac I (32), 3. Bgl II (110)

Table 1. Frequency of presence of DNA polymorphic sites in the $\beta$-globin gene cluster in different groups ${ }^{\mathrm{a}}$

\begin{tabular}{|c|c|c|c|c|c|c|c|c|c|c|}
\hline \multirow[t]{2}{*}{ Polymorphisms } & \multicolumn{2}{|c|}{ Greeks } & \multicolumn{2}{|c|}{ Italians } & \multicolumn{2}{|c|}{ Am. Blacks } & \multicolumn{2}{|c|}{ Indians } & \multicolumn{2}{|c|}{ S.E. Asians } \\
\hline & $\beta^{A}$ & $\beta^{\text {thal }}$ & $\beta^{A}$ & $\beta^{\text {thal }}$ & $\beta^{\mathrm{A}}$ & $\beta^{S}$ & $\overline{\beta^{A}}$ & $\beta^{\text {thal }}$ & $\overline{\beta^{A}}$ & $\beta^{\mathrm{E}}$ \\
\hline $\operatorname{Taq} I(1)$ & 1.00 & 1.00 & 1.00 & 1.00 & 0.88 & 0.41 & 1.00 & 1.00 & 1.00 & 1.00 \\
\hline Hind III (3) & 0.52 & 0.14 & 0.26 & 0.48 & 0.41 & 0.35 & 0.30 & 0.26 & 0.27 & 0.73 \\
\hline Hind III (4) & 0.30 & 0.07 & 0.06 & 0.37 & 0.16 & 0.05 & 0.06 & 0.09 & 0.04 & 0.00 \\
\hline Hinc II (7) & 0.48 & 0.12 & 0.28 & 0.31 & 0.76 & 0.81 & 0.27 & 0.17 & 0.27 & 0.73 \\
\hline Rsa I (8) & 0.37 & & 0.77 & & 0.50 & & 0.79 & & & \\
\hline Taq I (9) & 0.68 & & 0.23 & & 0.53 & & 0.27 & & & \\
\hline Hinf I (10) & 0.97 & 0.92 & 0.95 & 0.92 & 0.70 & 0.10 & 1.00 & 0.86 & 0.98 & 1.00 \\
\hline \multicolumn{11}{|l|}{ Rsa I (11) } \\
\hline Hind III (15) & 0.72 & & 0.73 & & 0.63 & & 0.56 & & & \\
\hline Bam HI (16) & 0.70 & 0.78 & 0.74 & 0.82 & 0.90 & 1.00 & 0.82 & 0.84 & 0.70 & 0.73 \\
\hline Rsa I (17) & 0.37 & 0.21 & 0.18 & 0.17 & 0.10 & 0.00 & 0.18 & 0.08 & & \\
\hline
\end{tabular}

a Computation of these data was performed in collaboration with Dr. A. Chakravarti and K. Buetow of the Department of Biostatistics at the University of Pittsburgh

blacks although they are very rare in other racial groups. In general, there is not a striking difference between the frequency of the presence $(+)$ of a polymorphism in $\beta^{A}$ and $\beta^{\text {variant }}$ chromosomes. However, in some cases there is linkage disequilibrium between the presence of a polymorphic site and the $\beta$-globin allele. For example, the Hinf I site (number 10 in Fig. 2) is present in $70 \%$ of $\beta^{A}$ chromosomes examined in American Blacks but only in $10 \%$ of the $\beta^{\mathrm{S}}$ chromosomes in this population. Other sites that show linkage disequilibrium with the $\beta$-globin allele include the Hpa I site (site 14) and the $\beta^{\mathrm{S}}$ allele in American and West African Blacks, and the Hind III sites ( 3 and 4$)$ and the $\beta^{\text {thal }}$ alleles in Greeks.

\subsection{Random versus non-random association of polymorphic sites}

If two polymorphic sites are randomly associated with each other, the probability of the presence of both sites $(++)$ is equal to the product of the probability of the presence of each site. For example, let us suppose that polymorphic site $\mathbf{I}$ is present in $50 \%$ of the chromosomes examined in a given population, and polymorphic site II is present in $30 \%$ of the chromosomes examined in the same population. The theoretical probability of the presence of both sites $(++)$ in the chromosomes of the particular population will be $50 \% \times 30 \%=$ $15 \%$, if the two sites are randomly associated. If they are nonrandomly associated, the probability of the presence of both will be significantly different from the expected. This non-randomness of association is termed linkage disequilibrium. The pattern or combination of polymorphic restriction sites for any chromosome is called a haplotype [1]. For a given number $n$ of polymorphic restriction sites there is a maximum of $2^{\mathrm{n}}$ possible combinations of sites with an expected frequency for each of those haplotypes equal to the product of the probabilities for every individual site. 
ruptions is maintained for short stretches [54]. Overall nearly $4 \mathrm{~kb}$ of DNA within the $\alpha$-globin complex is highly homologous and duplicated. This is in marked contrast to the $\beta$-globin gene cluster in which homologous regions are limited to portions of the exons. The high degree of broad homology in the alpha complex provides a large target size for recombination or crossing-over events in the DNA.

Acknowledgements. The authors thank Mrs. Emily Pasterfield for the preparation of this manuscript. We would especially like to express our thanks to C.D. Boehm, P. G. Waber, T.C.Cheng, P. V. Giardina, A.Li, S. Charache, J.Sexton, S. Goff, A.F.Scott, J.A.Phillips, K. Buetow, A. Chakravarti who contributed to much of the work reviewed here. We also are appreciate of our colleagues who shared with us preprints and unpublished data. This work was supported by grants from the NIH to HHK and SHO. SEA in the recipient of a New Investigator Research Award from the NIH.

\section{References}

1. Antonarakis SE, Boehm CD, Giardina PJV, Kazazian HH Jr (1982) Nonrandom association of polymorphic restriction sites in the $\beta$-globin gene cluster. Proc Natl Acad Sci USA 79:137-141

2. Antonarakis SE, Orkin SH, Kazazian HH Jr, Goff SC, Boehm CD, Waber PG, Sexton JP, Ostrer H, Fairbanks VF, Chakravarti A (1982) Evidence for multiple origin of the $\beta^{\mathrm{E}}$-globin gene in Southeast Asia. Proc Natl Acad Sci USA 79:6608-6611

3. Antonarakis SE, Orkin SH, Cheng T-c, Scott AF, Sexton JP, Trusko S, Charache S, Kazazian HH Jr (1984) $\beta$-Thalassemia in American Blacks: novel mutations in the TATA box and IVS-2 acceptor splice site. Proc Natl Acad Sci USA 81:1154-1158

4. Antonarakis SE, Boehm CD, Serjeant GR, Theisen CE, Dover GJ, Kazazian HH Jr (1984) Origin of the $\beta^{s}$ globin gene in Blacks: the contribution of recurrent mutation or gene conversion of both. Proc Natl Acad Sci USA 81:853-856

5. Arous N, Galacteros F, Fessas P, Loukopoulos D, Blouquit $\mathrm{X}$, Komis G, Sellaye M, Boussiou M, Rosa J (1983) Hemoglobin Knossos $\beta^{27}$ Ala-Ser presenting as a silent $\beta$-thalassemia. FEBS Lett 147:147-200

6. Baltimore D (1981) Gene conversion: some implications for immunoglobin genes. Cell 24:592-594

7. Bell GI, Selby JJ, Rutter WJ (1982) The highly polymorphic region near the insulin gene is composed of single tandemly repeated sequences. Nature 295:31-35

8. Bernards R, Flavell RA (1980) Physical mapping of the globin gene deletion in hereditary persistence of foetal haemoglobin (HPFH). Nucleic Acids Res 9:1521-1534

9. Bernards R, Kooter JM, Flavell R (1979) Physical mapping of the globin gene deletion in (delta-beta) ${ }^{\circ}$-thalassemia. Gene $6: 265-280$

10. Beutler E, Kuhl W, Johnson C (1981) A common mutant EcoRI restriction endonuclease site in the $5^{\prime}$ flanking portion of the human $\alpha$-globin gene. Proc Natl Acad Sci USA 78:7056-7058

11. Boehm CD, Antonarakis SE, Phillips JA, Stetten G, Kazazian HH Jr (1983) Prenatal diagnosis using DNA polymorphisms. N Engl J Med 308:1054-1058

12. Boehm CD, Antonarakis SE, Kazazian HH Jr (to be published) Evidence supporting a single origin of the $\beta^{\mathrm{C}}$ globin gene in Blacks. Am J Hum Genet

13. Boehm CD, Dowling CE, Kazazian $\mathrm{HH} \mathrm{Jr}$ (to be published) $\beta$-Thalassemia due to a rare deletion involving the $\beta$-globin gene in an American Black. Am J Hum Genet abstract

14. Breathnach R, Chambon P (1981) Organization and expression of eucaryotic split genes coding for proteins. Annu Rev Biochem 50:349-383

15. Capon DJ, Chen EY, Levison AD, Seeburg PH, Goeddel DV (1983) Complete nucleotide sequences of the T24 human bladder carcinoma oncogene and its normal homologue. Nature 302:33-37

16. Chakravarti A, Buetow KH, Antonarakis SE, Waber PG, Boehm CD, Kazazian HH Jr (to be published) Non-uniform recombination within the human $\beta$-globin gene cluster. Am J Hum Genet

17. Chang JC, Kan YW (1979) $\beta^{\circ}$-Thalassemia, a nonsense mutation in man. Proc Natl Acad Sci USA 76:2886-2889

18. Chang JD, Kan YW (1984) Deletion of the entire human $\alpha$-globin gene cluster. Clin Res 32:549A

19. Cheng T-c, Orkin SH, Antonarakis SE, Potter MJ, Sexton JP, Markham AF, Giardina PVJ, Li A, Kazazian HH Jr (1984) $\beta$ Thalassemia in Chinese: use of in vivo RNA analysis and oligonucleotide hybridization in systematic characterization of molecular defects. Proc Natl Acad Sci USA 81:2821-2825

20. Clegg JB, Weatherall DJ, Milner PF (1971) Hemoglobin Constant Spring - a chain termination mutation. Nature 234:337339

21. Collins FS, Weissman SM (to be published) The molecular genetics of human hemoglobins. Prog Nucleic Acids Res Mol Biol

22. Collins FS, Metherall J, Forget BG, Weissman SM (1984) Personal communication

23. Collins FS, Stoeckert CJ, Serjeant G, Forget BG, Weissman $\mathrm{SM}(1984){ }^{G} \gamma \beta^{+}$hereditary persistence of fetal hemoglobin: Cosmid cloning and identification of a specific mutation $5^{\prime}$ to the ${ }^{\mathrm{G}_{\gamma}}$ gene. Proc Natl Acad Sci USA 81:4894-4899

24. Deisseroth A, Nienhuis A, Lawrence J, Giles R, Turner P, Ruddle FH (1978) Chromosomal localization of human $\beta$-globin gene on human chromosome 11 in somatic cell hybrids. Proc Natl Acad Sci USA $75: 1456-1460$

25. Embury SH, Miller JA, Dozy AM, Kan YW, Chan V, Todd D (1980) Two different molecular organizations account for the single $\alpha$-globin gene of the $\alpha$-thalassemia- 2 genotype. J Clin Invest $66: 1319-1325$

26. Fearon ER, Kazazian HH Jr, Waber PG, Lee JI, Antonarakis SE, Orkin SH, Vanin EF, Henthorn PS, Grosveld FG, Scott AF, Buchanan GR (1983) The entire $\beta$-globin gene cluster is deleted in a form of $\gamma \delta \beta$-thalassemia. Blood 61: 1269-1274

27. Flavell RA, Kooter JM, DeBoer E, Little PFR, Williamson R (1978) Analysis of the beta-delta-globin gene loci in normal and $\mathrm{Hb}$ Lepore DNA: direct determination of gene linkage and intergene distance. Cell 15:25-41

28. Fritsch EF, Lawn RM, Maniatis T (1979) Characterization of deletions which affect the expression of fetal globin genes in man. Nature 279:598-603

29. Fritsch EF, Lawn RM, Maniatis T (1980) Molecular cloning and characterization of the human $\beta$-like globin gene cluster. Cell 19:959-973

30. Gilman JG, Huisman TH, Abels J (1984) Dutch $\beta^{\circ}$ thalassemia: a 10 kilobase DNA deletion associated with significant gamma chain production. Br J Hematol 56:339-348

31. Goldsmith ME, Humphries RK, Ley T, Cline A, Kantor J, Nienhuis AW (1983) Silent nucleotide substitution in $\beta^{+}$-thalassemia gene activating a cryptic splice site in $\beta$ globin RNA coding sequence. Proc Natl Acad Sci USA 80:2318-2322

32. Goodbourn SEY, Higgs DR, Clegg JB, Weatherall DJ (1983) Molecular basis of length polymorphism in the human z-globin gene complex. Proc Natl Acad Sci USA 80:5022-5026

33. Goossens M, Dozy AM, Embury SH, Zachariadis Z, Hadjiminas MG, Stamatoyannopoulos G, Kan YW (1980) Triplicated $\alpha$ globin loci in humans. Proc Natl Acad Sci USA 77:518-522

33A. Goossens M, Lee KY, Liebhaber SA, Kan YW (1982) Globin structural mutant $\alpha^{125}$ Leu $\rightarrow$ Pro is a novel cause of $\alpha$-thalassemia. Nature 296:864-866

34. Higgs DR, Goodbourn SEY, Wainscoat JS, Clegg JB, Weatherall DJ (1981) Highly variable regions of DNA flank the human a-globin genes. Nucleic Acids Res 9:4213-4224

35. Higgs DR, Goodbourn SEY, Lamb J, Clegg JB, Weatherall DJ, Proudfoot NJ (1983) A thalassemia caused by a polyadenylation signal mutation. Nature 306:398-400

36. Huisman THJ, Wrightstone RN, Wilson JB, Schroeder WA, Kendall G (1972) Hemoglobin Kenya, the product of fusion of $\gamma$ and $\beta$ polypeptide chains. Arch Biochem Biophys 152:850-855

37. Jackson JA, Fink GR (1981) Gene conversion between triplicated genetic elements in yeast. Nature 292:306-311

38. Jeffreys AJ (1979) DNA sequence variants in the ${ }^{\mathrm{G}} \gamma,{ }^{\mathrm{A}} \gamma, \delta$ and $\beta$ globin genes of man. Cell 18:1-10 
39. Jones RW, Old JM, Trent RJ, Clegg JB, Weatherall DJ (1981) Restriction mapping of a new deletion responsible for $\mathrm{G}$ gamma (delta beta) ${ }^{\circ}$-thalassemia. Nucleic Acids Res 9:6813-6825

40. Jones RW, Old JM, Trent RJ, Clegg JB, Weatherall DJ (1981) Major rearrangement in the human $\beta$-globin gene cluster. Nature 291:39-44

41. Kan YW, Dozy AM (1978) Polymorphism of DNA sequence adjacent to the human $\beta$-globin structural gene: relationship to sickle mutation. Proc Natl Acad Sci USA 75:5631-5635

42. Kan YW, Dozy AM (1980) Evolution of the hemoglobin S and $C$ genes in world populations. Science $209: 388-391$

43. Kan YW, Dozy AM, Trecatrin R, Todd D (1977) Identification of a non-deletion defect in $\alpha$-thalassemia. $N$ Engl $\mathrm{J}$ Med 297: 1081-1084

44. Kan YW, Dozy AM, Stamatoyannopoulos G, Hadjiminas MG, Zachariades Z, Furbetta M, Cao A (1979) Molecular basis of hemoglobin-H disease in the Mediterranean population. Blood $54: 1434-1438$

45. Kan YW, Lee KY, Furbetta M, Angius A, Cao A (1980) Polymorphism of DNA sequence in the $\beta$-globin gene region. $N$ Engl J Med 302: 185-188

46. Kazazian HH Jr, Orkin SH, Antonarakis SE, Sexton JP, Boehm CD, Goff SC, Waber PG (1984) Molecular characterization of seven $\beta$-thalassemia mutations in Asian Indians. EMBO J $3: 593-596$

47. Kazazian $\mathrm{HH} \mathrm{Jr}$, Chakravarti A, Orkin SH, Antonarakis SE (1983) DNA polymorphisms in the human $\beta$-globin gene cluster. In: Nei M, Koehn RK (eds) Evolution of genes and proteins. Sinauer Associates, Sunderland, pp 137-146

48. Kazazian HH JR, Antonarakis SE, Cheng T-c, Boehm CD, Waber PG (1983) Use of haplotype analysis of the $\beta$-globin gene cluster to discover $\beta$-thalassemia mutations. In: Stamatoyannopoulos G, Nienhuis AW (eds) Globin gene expression and hematopoietic differentiation. Alan R. Liss, New York, pp 9198

49. Kazazian HH Jr, Orkin SH, Boehm CD, Sexton JP, Antonarakis SE (1983) $\beta$-Thalassemia due to deletion of the nucleotide which is substituted in sickle cell anemia. Am J Hum Genet 35: 1028-1033

50. Kazazian HH Jr, Waber PG, Boehm CD, Lee JI, Antonarakis SE, Fairbanks VF (1984) Hemoglobin E in Europeans: further evidence for multiple origins of the $\beta^{\mathrm{E}}$ globin gene. Am J Hum Genet 36:212-217

51. Kazazian HH Jr, Orkin SH, Markham AF, Chapman CR, Youssoufian HA, Waber PG (1984) Quantification of the close association between DNA haplotypes and specific $\beta$-thalassemia mutations in Mediterraneans. Nature 300:152-154

52. Kimura A, Matsunaga E, Takihara $Y$, Nakamura T, Takagi $Y$, Lin ST, Lee HT (1983) Structural analysis of a $\beta$-thalassemia gene found in Taiwan. J Biol Chem 258:2748-2749

53. Kinniburgh AJ, Maquat LE, Schedl T, Rachmilewitz E, Ross J (1982) mRNA-deficient $\beta$-thalassemia results from a single nucleotide deletion. Nucleic Acids Res 10:5421-5427

54. Lauer J, Shen C-KJ, Maniatis T (1980) The chromosomal arrangement of human $\alpha$-like globin genes. Sequence homology and $\alpha$-globin gene deletions. Cell 20:119-130

55. Lawn RM, Efstratiadis A, O'Connell C, Maniatis T (1980) The nucleotide sequence of the human $\beta$-globin gene. Cell 21 :647651

56. Liebhaber SA, Goossens M, Poon R, Kan YW (1980) The primary structure of the $\alpha$-globin gene cloned from normal human DNA. Proc Natl Acad Sci USA 77:7054-7058

57. Lie-Injo LE, Hereva AR, Kan YW (1981) Two types of triplicated $\alpha$-globin loci in humans. Nucleic Acids Res 9:3707-3713

58. Maeda N, Bliska JB, Smithies O (1983) Recombination and balanced chromosome polymorphism suggested by DNA sequences 5 ' to the human $\gamma$-globin gene. Proc Natl Acad Sci USA $80: 5012-5016$

59. Maniatis T, Hardison RC, Lacy E, Lauer J, O'Connell C, Quon D, Sim GK, Efstratiadis A (1978) The isolation of structural genes from libraries of eucaryotic DNA. Cell 15:687-701

60. Maniatis T, Fritsch EF, Lauer J, Lawn RM (1980) The molecular genetics of human hemoglobins. Annu Rev Genet 14:145178
61. Miesfeld R, Krystal M, Arnheim N (1981) A member of a new repeated sequence family which is conserved throughout eucaryotic evolution is found between the human $\delta$ and $\beta$ globin genes. Nucleic Acids Res 9:5931-5947

62. Moschonas N, deBoer E, Grosveld FG, Dahl HHM, Shewmaker CK, Flavell RA (1981) Structure and expression of a cloned $\beta$-thalassemia globin gene. Nucleic Acids Res 9:43914401

63. Mount SM (1982) A catalog of splice junction sequences. Nucleic Acids Res 10:459-472

64. Nathans D, Smith HO (1975) Restriction endonucleases in the analysis and restructuring of DNA molecules. Annu Rev Biochem 44:273-290

65. Old JM, Wainscoat JS (1983) A new DNA polymorphism in the $\beta$-globin gene cluster can be used for antenatal diagnosis of $\beta$ thalassemia. Br J Hematol 53:337-341

66. Orkin SH, Goff SC (1981) Nonsense and frameshift mutations in $\beta^{\circ}$-thalassemia detected in cloned $\beta$-globin genes. $\mathrm{J}$ Biol Chem 256:9782-9784

67. Orkin SH, Michelson A (1980) Partial deletion of the alpha-globin structural gene in human alpha-thalassemia. Nature $286: 538-540$

68. Orkin SH, Old JM, Weatherall DJ, Nathan DG (1979) Partial deletion of $\beta$-globin gene DNA in certain patients with $\beta^{\circ}$-thalassemia. Proc Natl Acad Sci USA 76:2400-2404

69. Orkin SH, Blanche PS, Cigdem A (1979) Deletion of the Agamma-globin gene in G-gamma-delta-beta-thalassemia. J Clin Invest 64: 866-869

70. Orkin SH, Goff SC, Nathan DG (1981) Heterogeneity of DNA deletion in gamma-delta-beta thalassemia. J Clin Invest 67:878884

71. Orkin SH, Goff SC, Hechtman RL (1981) Mutation in the intervening sequence splice junction in man. Proc Natl Acad Sci USA $78: 5041-5045$

72. Orkin SH, Kazazian HH Jr, Antonarakis SE, Goff SC, Boehm CD, Sexton JP, Waber PG, Giardina PVJ (1982) Linkage of $\beta$ thalassemia mutations and $\beta$-globin gene polymorphisms with DNA polymorphisms in the human $\beta$-globin gene cluster. Nature 296:627-631

73. Orkin SH, Kazazian HH Jr, Antonarakis SE, Ostrer H, Goff SC, Sexton JP (1982) Abnormal RNA processing due to the exon mutation of the $\beta^{\mathrm{E}}$-globin gene. Nature $300: 768-769$

74. Orkin SH, Sexton JP, Cheng TC, Goff SC, Giardina PVJ, Lee JI, Kazazian HH Jr (1983) TATA box transcription mutation in $\beta$-thalassemia. Nucleic Acids Res 11:4721-4734

75. Orkin SH, Antonarakis SE, Kazazian HH Jr (1983) Polymorphism and molecular pathology of the $\beta$-globin gene. Prog Hematol 13:49-73

76. Orkin SH, Markham AF, Kazazian HH Jr (1983) Direct detection of the common Mediterranean $\beta$-thalassemia gene with synthetic DNA probes. J Clin Invest 71:775-779

77. Orkin SH, Antonarakis SE, Kazazian HH Jr (1984) Base substitution at position -88 in a $\beta$-thalassemia globin gene: further evidence for the role of distal promoter element ACACCC J Biol Chem 259:8679-8681

78. Orkin SH, Antonarakis SE, Louropoulos D (1984) Abnormal processing of the $\beta^{\text {Knossos }}$ gene. Blood 64:311-313

79. Orkin SH, Cheng TC, Antonarakis SE, Kazazian HH Jr (1984) Inhibition of RNA cleavage in $\beta$-thalassemia by a mutation in the $3^{\prime}$ consensus sequence AAUAAA. Am J Hum Genet 36:149 S

80. Ottolenghi S (1984) Personal communication

81. Pagnier J, Mears JG, Dunda-Belkodja O, Schaefer-Rego KE, Belford C, Nagel RL, Labie D (1984) Evidence for the multicentric origin of the $\beta^{S}$ globin gene in Africa. Proc Natl Acad Sci USA $81: 1771-1773$

82. Pirastu M, Kan YW, Lin CC, Baine RM, Holbrook CT (1983) Hemolytic disease of the newborn caused by a new deletion of the entire $\beta$-globin cluster. J Clin Invest 72:602-609

83. Pirastu M, Curtin P, Kan YW (1984) Gene deletion distant from the $\beta$-globin locus inactivates the $\beta$-globin gene. Clin Res $32: 493 \mathrm{~A}$

84. Pirastu M, Kan YW, Galanello R, Cao A (1984) Multiple mutations produce $\delta \beta$ thalassemia in Sardinia. Science 223:929-930 
85. Pirastu M, Sagho G, Cao A, Kan YW (1984) An initiation codon mutation in alpha thalassemia. Clin Res 32:550A

86. Poncz M, Ballantine M, Solowiejczyk D, Barak J, Schwartz E, Surrey S (1982) $\beta$-Thalassemia in a Kurdish Jew. J Biol Chem 257:5994-5996

87. Pirastu M, Kan YW, Cao A, Conner BJ, Teplitz RL, Wallace RB (1983) Direct analysis of point mutations by hybridizing with synthenic oligomers. N Engl J Med 309:284-287

88. Reference deleted

89. Pressley L, Higgs DR, Clegg JP, Perrine PR, Pembrey ME, Weatherall DJ (1980) A new genetic basis for hemoglobin $\mathrm{H}$ disease. N Engl J Med 303:1383-1386

90. Pressley L, Higgs DR, Aldridge B, Metaxatou-Mavromati A, Clegg JB, Weatherall DJ (1980) Characterization of a new alpha-thalassemia-1 defect due to a partial deletion of the alpha globin gene complex. Nucleic Acids Res 8:4889-4898

91. Pressley L, Higgs DR, Clegg JB, Weatherall DJ (1980) Gene deletions in alpha thalassemia prove that the $5^{\prime}$ zeta locus is functional. Proc Natl Acad Sci USA 77:3586-3589

92. Proudfoot NJ, Maniatis T (1980) The structure of a human $\alpha-$ globin pseudogene and its relationship to $a$-globin gene duplication. Cell 21:537-544

93. Proudfoot NJ, Gil A, Maniatis T (1982) The structure of the human zeta-globin gene and a closely linked, nearly identical pseudogene. Cell 1:553-563

94. Roberts RJ (1980) Directory of restriction endonucleases. Methods Enzymol 65:1-15

95. Sakumaran PK, Nakatsuji T, Gardiner MB, Reese AL, Gilman JG, Huisman TH (1983) Gamma thalassemia resulting from the deletion of a ${ }^{G} \gamma$-globin gene. Nucleic Acids Res 11:4635-4643

96. Scott AF, Heath P, Trusko S, Boyer SH, Prass W, Goodman M, Caelusniak J, Chang LYE, Slighton JL (1984) The sequence of the gorilla fetal $\gamma$-globin genes: evidence for multiple gene conversions in human evolution. Mol Biol Evol 1:371-389

97. Semenza GL, Malladi P, Poncz M, Delgrosso K, Schwartz E, Surray $S$ (1984) Detection of a novel DNA polymorphism in the $\beta$-globin cluster and evidence for site-specific recombination. Clin Res 18:225A

98. Shen S, Slightom JL, Smithies O (1981) A history of the human fetal globin gene duplication. Cell 20:191-203

99. Southern EM (1978) Detection of specific sequences among DNA fragments separated by gel electrophoresis. J Mol Biol 98:503-517

100. Spense SE, Pergolizzi RG, Donovan-Pelluso M, Kosche KA, Dobkin CD, Bank A (1982) Five nucleotide changes in the large intervening sequence of $\beta$-globin gene in a $\beta$-thalassemia patient. Nucleic Acids Res 10:1283-1294
101. Spritz RA (1981) Duplication deletion polymorphisms 5 to the human $\beta$-globin gene. Nucleic Acids Res 9:5037-5047

102. Spritz RA, Orkin SH (1982) Duplication followed by deletion accounts for the structure of an Indian deletion $\beta$-thalassemia gene. Nucleic Acids Res 10:8025-8029

103. Spritz RA, Jagadeeswaran P, Choudary PV, Biro PA, Elder JT, DeRiel JK, Manley JL, Gefter ML, Forget BG, Weissman SM (1981) Base substitution in an intervening sequence of a $\beta$ thalassemic human globin gene. Proc Natl Acad Sci USA $78: 2455-2459$

104. Tilghman SM, Tiemeier DC, Seidman JG, Peterlin BM, Sullivan M, Maizel JV, Leder P (1978) Intervening sequence of DNA identified in the structural portion of a mouse $\beta$-globin gene. Proc Natl Acad Sci USA 75:725-729

105. Trecartin RF, Liebhaber SA, Chang JC, Lee KY, Kan YW (1981) $\beta^{\circ}$-Thalassemia in Sardinia is caused by a nonsense mutation. J Clin Invest 68:1012-1017

106. Treisman RA, Proudfoot NJ, Shander M, Maniatis T (1982) A single base change at a splice site in a $\beta^{\circ}$-thalassemic gene causes abnormal RNA splicing. Cell 29 : 903-911

107. Treisman RA, Orkin SH, Maniatis T (1983) Specific transcription and RNA splicing defects in five cloned $\beta$-thalassemia genes. Nature 302:591-596

108. Tuan D, Feingold E, Newman M, Weissman SM, Forget BG (1983) Different $3^{\prime}$ endpoints of deletions causing $\beta$-thalassemia and HPFH. Proc Natl Acad Sci USA 80:6937-6941

109. Van der Ploeg LHT, Konings A, Oort M, Roos D, Bernini L, Flavell RA (1980) Gamma-beta-thalassemia studies showing that detection of the gamma- and delta-genes influences betaglobin gene expression in man. Nature 283:637-642

110. Wainscoat JS, Higgs DR, Kanavakis E, Cao A, Georgiou D, Clegg JB, Weatherall DJ (1983) Association of two DNA polymorphisms in the $\alpha$-globin gene cluster: implications for genetic analysis. Am J Hum Genet 35 : 1086-1089

111. Weatherall DJ, Clegg JB (1976) Molecular genetics of human hemoglobins. Annu Rev Genet 10:157-170

112. Weatherall DJ, Higgs DR, Bunch G, Old JM, Hunt DM, Pressley L, Clegg JB, Nethlengalay NC, Sjolin MD, Kolen RD, Maganis E, Francis JL, Bebbington D (1981) Hemoglobin H disease and mental retardation, a new syndrome or a remarkable coincidence? N Engl J Med 304:607-610

113. Westaway D, Williamson R (1981) An intron nucleotide sequence variant in a cloned $\beta$-thalassemia globin gene. Nucleic Acids Res 9:1777-1788

Received June 19, 1984

\section{Note added in proof (November 6, 1984)}

Since the submission of this review several new mutations have been found in the $\beta$-globin gene cluster.

1. $\beta^{+}$thalassemia gene due to a transcriptional mutation in a Japanese patient. The mutation is an A-T change in position -31 in the TATA box of the $\beta$-globin gene (Fukumaki Y, Yamada H, Kimura A, Nakamura T, Matsunaga E, Takihara Y, Tagaki Y. A new deletion in $\beta$ thalassemia and a new TATA box mutation in $\beta^{+}$thalassemia in Japan 1984. Abstract, 4th Conference on Hemoglobin Switching, Airlie, Virginia).

2. $\beta^{\circ}$ thalassemia gene due to a splicing mutation in a Greek patient. The mutation is a G-T change in IVS-1 nt 5 (Forget BG, Weissman SM, 1984, personal communication).

3. $\beta^{\circ}$ thalassemia gene due to a splicing defect in a patient from Kuwait. The mutation is a deletion of 17 nts which abolishes the acceptor splice site of IVS-1.

4. One form of ${ }^{\mathrm{A}} \gamma \mathrm{HPFH}$ in Greeks is due to a G-A change in position -117 from the ${ }^{\mathrm{A}} \gamma$ gene. This change occurs just $2 \mathrm{nts}$ upstream of the distal CAT box of the ${ }^{A} \gamma$ gene (Gelinas R, Stamatoyannopoulos G, et al, 1984, Abstract, 4th Conference on Hemoglobin Switching, Airlie, Virginia and Collins FS, Weissman SM, Forget BG, et al, 1984, Abstract, 4th Conference on Hemoglobin Switching, Airlie, Virginia).

In addition, a few new deletions in the $\beta$-globin gene cluster have also been described at the recent 4 th Hemoglobin Switching meeting.

1. $\delta \beta$ thalassemia in an American Black. This deletion starts $5^{\prime}$ to $\delta$, but after two Alu I sequences $5^{\prime}$ to $\delta$ (Anagnou N, Nienhuis AW, NIH, 1984).

2. HPFH type III in an Indian patient. This deletion extends $5^{\prime}$ to HPFH type II, but the ${ }^{\mathrm{A}} \gamma$ gene is intact (Mager D, Smithies O, Madison, Wisc. 1984).

3. $\left({ }^{A} \gamma \delta \beta\right)^{\circ}$ thalassemia in a German patient. The deletion starts between ${ }^{G} \gamma$ and ${ }^{A} \gamma$ and extends $3^{\prime}$ to $\beta$-globin gene (Anagnou $N$, Nienhuis AW, NIH, 1984).

4. $\delta \beta$ thalassemia in a Japanese patient. The deletion starts between ${ }^{\mathrm{A}} \gamma$ and $\psi \beta_{1}$ and extends an unknown distance $3^{\prime}$ to $\beta$-globin gene (Fukumaki Y, et al, Fukuoka, Japan, 1984).

5. HPFH type IV in an Italian patient. The deletion starts in a narrow region of $70 \mathrm{nts}$ of the non-repetitive DNA between the two Alu I repeats $5^{\prime}$ to $\delta$ globin gene and extends an unknown distance to $\beta$-globin gene (Ottolenghi S et al, Milan, 1984). 